\title{
Análise de situações de trabalho: gestão e os usos de si dos trabalhadores de uma empresa do ramo petrolífero
}

\section{Analysis of work situations: management and the uses of itself of the workers of a company of the petroliferous branch}

\author{
Estevam Luiz Nascimento Lima ${ }^{1}$ \\ Mônica de Fátima Bianco ${ }^{2}$
}

\begin{abstract}
Resumo
Este artigo pretende expor as nuances do mundo do trabalho. Discute o trabalho como construção histórica e o contexto atual na gestão de seus processos. Busca-se, em primeiro lugar, entender a relação do trabalhador com os processos de trabalho, com base nos conceitos da ergologia como perspectiva de análise. Para tanto, é apresentado um estudo de caso numa empresa atuante na área de fabricação de tubos flexíveis para exploração de petróleo. A produção dos dados foi obtida por meio de pesquisa documental, com uso de observação participante, reuniões de validação e análise dos dados, assim como entrevistas individuais semiestruturadas. Situações de trabalho e suas complexidades foram analisadas, obtendo-se o entendimento sobre aspectos importantes de como os trabalhadores do setor estudado interagem entre si e com as situações de trabalho, compreendendo os usos de si dos mesmos na gestão de suas atividades.
\end{abstract}

Palavras-chave: Trabalho. Gestão. Usos de si. Ergologia.

\begin{abstract}
This article intends to display nuances of the world of work. It argues the work as an historical construction and the current context in the management of its processes. Firstly, it aims to understand the worker and their relations with the work processes, based on the concepts of ergology as a perspective of analysis. In order to reach this objective, it is presented a case study of a company in the area of manufacture of flexible pipes for oil exploration. Data were collected through documentary research, with the use of participant observation, meetings of validation and analysis of the data, as well as semi-structured interviews. Work situations and its complexities had been analyzed, getting the agreement on important aspects related to how workers belonging to the analyzed sector interact between them as well as with work situations, understanding the uses of itself of the same ones in the accomplishment of its activities.
\end{abstract}

Keywords: Work. Management, Uses of itself, Ergology

\section{Introdução}

O mundo do trabalho atravessa um processo de reestruturação produtiva e organizacional, cujas inflexões apontam para o esgotamento do modelo taylorista-fordista, estabelecendo novos cenários produtivos. Para Abrahão e Pinho (2002), essa reestruturação pode ser identificada pela transformação das estruturas e estratégias empresariais, assim como a modernização das tecnologias empregadas na produção, que alteram as formas de organização, gestão e controle do trabalho. Entre os resultados, estão novas formas de

\footnotetext{
1 Mestre em Administração. .Professor da Pós-Graduação em Engenharia de Produção das Faculdades Integradas Espírito-Santatense s- FAESA. Coordenador de Produção da Chocolates Garoto S.A.Endereço: Praça Meyerfreund, 1 - Glória - Vila Velha/Espírito Santo - Brasil - CEP:29122-900. e-mail: estevam.lima@garoto.com.br

2 Doutora em Engenharia de Produção. Professora do Programa de Pós-Graduação em Administração da Universidade Federal do Espírito Santo-Professor Associado II. Endereço: Av. Fernando Ferrari, 514, Goiabeiras - Vitória/Espírito Santo - Brasil - CEP: 29075-910. E-mail: mfbianco@npd.ufes.br
}

Artigo submetido em janeiro e aceito em dezembro de 2008 
competitividade, com repercussões nos âmbitos administrativo e operacional e a busca da ampliação da produtividade do trabalho por meio da "revolução" tecnológica. Essas mudanças se manifestam, ainda, por alterações na natureza do trabalho, aumentando sua densidade, seu ritmo e a ampliação da jornada de trabalho; na co-habitação da "velha" organização com tecnologias gerenciais supostamente "modernizadoras".

Nota-se que importantes alterações estão em curso; alterações que ressaltam fatores psicossociais como a relação comunicacional, a dimensão coletiva, a relativa autonomia, as necessárias mobilizações subjetivas e a implicação dos trabalhadores nos processos de trabalho, assim como novos mecanismos de controle. As empresas, por sua vez, estimulam a realização de estudos e pesquisas organizacionais que em grande parte se concentram em buscar formas de organização do trabalho propiciadoras de maiores índices produtivos, 'esquecendo-se' da relevância do fator humano na produção.

Por este motivo, faz-se necessário perceber que o trabalhador desempenha um papel preponderante em situações de trabalho nas organizações e é um elemento determinante para a compreensão dessas situações, na medida em que ele as singulariza e renova.

Com base nesses princípios, surgem os estudos que diferenciam o trabalho prescrito e o trabalho real, pois a racionalidade não dá conta de todas as incertezas e/ou dos eventos que envolvem as situações de trabalho. Na execução da tarefa, a realização do trabalho real sempre difere da prescrição, pois a atividade de trabalho é complexa e singular. Os trabalhadores elaboram maneiras de realizar suas tarefas e alternativamente redefinem suas atividades, de forma a, no mínimo, amenizar as dificuldades existentes.

O estudo desses temas - conforme proposto pela ergologia - implica o entrecruzamento das formas de interação dos trabalhadores com o trabalho que executam e resulta em oportunidade de colaborar com a construção do conhecimento na referida área.

Nesse sentido, a presente pesquisa tem como objetivo analisar a complexidade das situações de trabalho e buscar entender como os trabalhadores da empresa estudada interagem entre si e com as situações de trabalho na realização de suas atividades.

Percebe-se a importância dos estudos das situações de trabalho, complexas, singulares, reconstruídas a cada momento. Essa compreensão está aliada à necessidade de considerar o homem como elemento central desses estudos, pois os conhecimentos resultantes dos homens em suas atividades podem ser utilizados para que os mesmos gerenciem seu trabalho. Consequentemente, a discussão desses processos como forma de construção do conhecimento e de práticas organizacionais mais humanizadas deve ser suscitada e ampliada, podendo ter embasamento em conceitos da ergologia, que ora se busca elucidar.

Para atingir esse objetivo, uma revisão de literatura sobre os temas em discussão é realizada nesta pesquisa. Em primeiro lugar, é feita uma explanação sobre os conceitos da ergologia, tendo como foco o ser humano no trabalho, procurando elucidar aspectos das situações de trabalho: o trabalho como construção histórica; as noções de tarefa, trabalho prescrito, normas antecedentes e atividade de trabalho, assim como de gestão e usos de si dos trabalhadores. Em seguida, os aspectos metodológicos são apresentados e as situações de trabalho analisadas, buscando compreender as interações dos trabalhadores no efetivo ato de trabalhar.

\section{Ergologia: uma perspectiva de análise do trabalho}

A ergologia parte da análise cuidadosa dos estudos indicativos da distância entre o trabalho prescrito e o real. Não vê o homem como uma variável de ajuste, mas procura agir nas situações de trabalho para que elas contribuam para permitir ao homem crescer, pois é uma abordagem que tem como ponto de partida e chegada a atividade. Ela é definida como o estudo das atividades humanas naquilo que elas exigem, a fim de serem apreciadas e conhecidas; sendo o encontro de múltiplos saberes e experiências diversas (DANIELLOU, 2004; FRANÇA in FIGUEIREDO et al., 2004).

Schwartz (in DANIELLOU, 2004) afirma que ergologia significa uma nova conduta no campo das ciências humanas que objetiva conhecer as situações de trabalho na perspectiva de intervenções que visem a transformar 
e melhorar essas situações. Não se trata de uma nova disciplina, mas de um complexo de condutas no campo das ciências humanas, do trabalho e suas diversas disciplinas (inclusive a ergonomia) e no campo da saúde do trabalhador, tendo como elemento operador, sintético e transdisciplinar o conceito de atividade humana no trabalho.

São quatro seus pressupostos: a) pensar o geral e o específico; b) articular diversas disciplinas entre si e interrogar sobre seus saberes; c) encontrar, em todas as atividades, normas antecedentes e variabilidades, normas que se impõem e instauram, assim como entender que a análise do trabalho é inseparável do campo dos valores, da epistemologia e da ética; d) promover um regime de produção de saberes sobre o ser humano, pois o encontro histórico entre os dois saberes - científico e prático - não pode ser antecipado, é sempre uma descoberta (BARROS e FONSECA, 2004; BRITO in FIGUEIREDO et al., 2004).

Logo, o objetivo da abordagem ergológica deve ser a elaboração da vivência das atividades humanas, desvendando a vivência dos sujeitos em relação à organização do trabalho e percebendo o que é fonte de pressões, dificuldades, desafios, suscetíveis de gerar inquietações e prazer. A ergologia vê o homem como um sujeito que pensa sua relação com o trabalho, produz interpretações dessa situação e de suas condições, socializa-as em atos intersubjetivos, reage e se reorganiza mental, afetiva e fisicamente. Em função de suas interpretações, age, enfim, sobre o próprio processo de trabalho e traz uma contribuição à construção e à evolução das relações sociais do trabalho.

\section{Trabalho: uma construção chela de história}

A vida humana, que é em parte uma experiência, se encontra atravessada de história. Quando se trata do trabalho, entretanto, tem-se uma história marcada pelo acaso de vidas individuais. Por conseguinte, nenhuma situação humana carrega tantos sedimentos, tantas condensações e marcas de debates de história das sociedades humanas quanto situações de trabalho (SCHWARTZ, 2003). Os conhecimentos colocados em ação, os sistemas produtivos, as tecnologias utilizadas, as formas de organização, os procedimentos escolhidos, os valores de uso selecionados e as relações sociais que se entrelaçam e opõem os homens cristalizam produtos da história da humanidade.

Toda situação de trabalho, pode-se dizer, está saturada de normas de vida, formas de exploração da natureza e dos homens uns pelos outros. Essa história que ultrapassa os sujeitos, fabrica-os, é em parte inacabada, incapaz de fazê-los compreender, por ela mesma, como produzem sua vida na atividade de trabalho (SCHWARTZ, 2003; 2005). Assim, se faz história em toda atividade de trabalho. Homens e mulheres em atividade reinterrogam os saberes e re-produzem novas tarefas para o conhecimento.

Neste sentido, os valores, as escolhas de ser de indivíduos e coletivos humanos exploram os recursos técnicos, científicos e sociais existentes e os reorganizam para produzir novas combinações. Essas fazem história e ao conhecimento conceitual cabe tentar compreender essas renormatizações operativas.

Todavia, esses saberes produzidos na atividade de trabalho não podem ser circunscritos, antecipados ou dados com a descrição de uma situação de trabalho particular, singular. Pensar dessa forma seria retornar a vigência das normas prescritivas. No que diz respeito ao trabalho e aos indivíduos, "simplesmente, os possíveis se engendram continuamente a partir das condições iniciais" (SCHWARTZ, 2000a, p.49; 2003). É por isso que o trabalho - essa construção cheia de história — sempre reserva surpresas.

Schwartz (1996) afirma que há dois modos extremos de se caracterizar o trabalho: ou ele é simples (reduzido a uma troca de tempo por salário, fonte de retribuição, meio de vida) ou uma realidade complicada para ser compreendida (acumula a herança de seus sucessivos nascimentos). Para o autor, "simplificar o trabalho é o início de qualquer ineficácia" (in FIGUEIREDO et al., 2004, p.31). Dessa forma, trabalho monótono, repetitivo, tarefas aparentemente sem significado, oferecendo poucos desafios ou autonomia, causam descontentamento entre trabalhadores de todos os níveis, pois "os trabalhadores não suportam mais a falta de interesse sobre sua capacidade de conhecer, desenvolver, criar e opinar a respeito de seu trabalho" (KAWAKAMI et al., 2004, p. 196). 
Por um lado, mesmo em condições opressivas de trabalho, as pessoas encontram pequenos espaços para situar o sentido de seu trabalho. Sendo assim, segundo Dejours (1991), embora haja dificuldades na relação entre a pessoa e sua necessidade de prazer e a organização do trabalho - que tende a um automatismo 'perfeito' e a tentar transformar o trabalhador num modelo de máquina -, "entre o homem e a organização há um espaço para negociações, ações e invenções do operador para adaptar o trabalho às suas necessidades e desejos" (DEJOURS; ABDOUCHELI; JAYET, 1994, p.15). Consequentemente, quando essa relação funciona, tanto a organização quanto os trabalhadores lucram (KAWAKAMI et al., 2004).

Por outro lado, um intuito da organização do trabalho seria reduzir o conhecimento da atividade de trabalho ao necessário para o funcionamento da mesma (GUÉRIN et al., 2004). Nesse sentido, a organização do trabalho diz respeito à definição de tarefas e à preparação do trabalho, à tentativa de separação entre a função organizadora e a atividade de trabalho, havendo dissociação entre atividade e gestão da atividade. Momento propício para se falar de gestão e gestores, trabalho prescrito e real, tarefa e atividade.

\section{Noções de tarefa, trabalho prescrito, normas antecedentes e atividade de trabalho}

A definição de tarefa remete a um modo concreto de apreensão do trabalho que tem por objetivo reduzir ao máximo o trabalho improdutivo e otimizar o produtivo (GUÉRIN et al., 2004). O conceito corresponde a um conjunto de objetivos e prescrições definidas externamente, dado aos trabalhadores para atingir esses objetivos particulares. A tarefa, no entanto, frequentemente não leva em conta as particularidades dos trabalhadores, sendo exterior aos mesmos e imposta. Contudo, os estudiosos do trabalho sabem perfeitamente que a estrita aplicação de prescrições conduziria ao desperdício, à insuficiência (SCHWARTZ, 2000a).

Na ergologia, outra expressão é importante: normas antecedentes. Essas se referem a construções históricas, resultado de um patrimônio conceitual, científico e cultural, de saberes-fazer historicamente constituídos no trabalho, enfim, aquisições da inteligência coletiva e da experiência acumulada e, pode-se dizer patrimônio da humanidade como um todo (BARROS; FONSECA, 2004). Como é um saber coletivo e disponibilizado, as normas antecedentes significam processos de antecipação do trabalho a realizar.

No entanto, há lacunas nas normas antecedentes e nos saberes. O que significa ter que se trabalhar de outro modo, diferente do que está determinado por tais normas; pois as escolhas (do trabalho vivo) trazem mais ou menos engenhosidade e criatividade, recombinando experiências e saberes em toda atividade realizada (SCHWARTZ, 2003).

Por um lado, os sujeitos doam-se às normas para o enfrentamento das variabilidades, engajando-se num processo de antecipação do que pode ir contra si. Por outro, nas situações de trabalho em que os indivíduos devem arbitrar e encontrar os meios para atingir os objetivos, há um processo de retrabalho das normas antecedentes — renormatização — pois todo homem quer ser sujeito de suas próprias normas. Essa é a dimensão irredutivelmente política do trabalho, por isso considerada dimensão política da produção e da legitimação de saberes no trabalho (SCHWARTZ, 2003; 2000a).

Assim, no ato de trabalho, as normas antecedentes são norteadoras, mas cada momento de confrontação entre os saberes é singular e ninguém pode substituir aquele que vive a experiência para julgar seus limites e horizontes.

Outro termo, do qual a ergologia faz uso para pensar o seu objeto é a atividade de trabalho. Essa é uma construção original de um indivíduo particular em dada situação, não sendo, portanto, previsível em sua singularidade (DANIELLOU, 2004). Quer dizer, a atividade de trabalho é mais que a realização de uma tarefa ou execução do trabalho prescrito, considerando-se restrições e vantagens dispostas pelas variabilidades; pois trata-se de uma estratégia de adaptação à situação real de trabalho. Sendo assim, a distância entre o prescrito e o real é a manifestação concreta da contradição presente no ato de trabalho, entre o que é pedido e o que "a coisa pede". Por isso, ao se aproximar de seu objeto — o trabalho humano — em situações reais, a ergologia mostra que o trabalho efetuado não corresponde ao trabalho esperado, visto que ao realizar a tarefa, a pessoa se encontra diante de diversas fontes de variabilidades (BOUTET et al., 1998). 
Considerando o que foi dito acima, nenhuma atividade pode ser avaliada como puramente manual, pois à atividade mental necessária para executar o trabalho prescrito é acrescentada outra mais complexa e indispensável, que é regular as variações do sistema. O não reconhecimento da significância das disfunções dos sistemas técnicos e organizacionais e o mau conhecimento do modo de funcionamento do ser humano são duas razões para o distanciamento entre trabalho prescrito e real (DANIELLOU; LAVILLE; TEIGER, 1983). É verdade que, ao realizar uma tarefa, o trabalhador se encontra diante de um quadro de variabilidades associadas aos seres humanos e ao coletivo. Logo, o real da atividade é também e igualmente aquilo que não se faz, o que se procura fazer sem lograr êxito, o que se queria ou poderia fazer, aquilo que se pensa poder fazer em outras situações. Fazer, então, é refazer e desfazer (CLOT, 2006).

Cabe aqui ressaltar que entre fazer e fazer rápido existem diferenças importantes. Não se trata simplesmente de agir com mais velocidade, mas agir de outra forma, reorganizando as sequências de tomada de informação e de gestos. Essa modificação não é uma questão de inteligência, mas de experiência, o que requer um tempo significativo, desconsiderando instruções e prescrições dadas.

O trabalho real é, então, a unidade da atividade de trabalho, das condições reais e dos resultados efetivos dessa atividade (DANIELLOU; LAVILLE; TEIGER, 1983). Nesse contexto, a perspectiva ergológica se coloca como um importante intercessor, porquanto fazendo a ruptura com as perspectivas que se limitam ao que é previsível no trabalho (modos operatórios), assume a hipótese de que é impossível que não exista atividade. Nas situações de trabalho, o indivíduo não se detém na tarefa que lhe é prescrita, pois o sujeito da atividade é alguém carregado de valores. O que distancia o prescrito do real são as escolhas, os julgamentos, orientados por esses critérios e valores.

A dimensão criativa, por conseguinte, não pode ser eliminada, pois todos os sujeitos, enquanto trabalham, produzem a existência, fazem história. A atividade de trabalho é, então, a maneira pela qual as pessoas se engajam no cumprimento dos objetivos do trabalho, servindo-se dos meios que estão disponíveis. "O trabalhador nela se engaja por inteiro" (NOUROUDINE in FIGUEIREDO et al., 2004, p. 60).

\section{Trabalho: usos de sl e gestão}

Seguindo a ideia de que o trabalhador se engaja na execução do seu trabalho, pode-se afirmar que toda atividade de trabalho é uma 'dramática do uso de si', o confronto entre as normas antecedentes e a necessidade de renormatização. Assim, cada situação de trabalho coloca questões novas e é também uma forma de autoexperimentação.

Schwartz (2000a) explica que todo trabalho é uso dramático de si: uso de si por outros e uso de si por si. Sendo uso de si, o trabalho passa ao lugar de um problema, uma tensão, um espaço de possíveis a ser negociado.

O uso, porém, não é apenas aquele que é feito de você, mas também aquele que você faz de si próprio, que cada um faz de si mesmo (NOUROUDINE in FIGUEIREDO et al., 2004; SCHWARTZ, 2000a). É o indivíduo no seu ser que é convocado, como recursos e competências para o trabalho, o que não se identifica com capacidade de se realizar a tarefa. Logo, tal é a justificação da palavra "uso" e a forma indiscutível de manifestação de um "sujeito" (SCHWARTZ, 2000a).

Schwartz (2000a) salienta que é a confrontação entre uso ou mau uso relativo que se faz de si e o uso limitado, mas testemunho de si por si, que suporta o peso respectivo desses usos nas experiências concretas do trabalho. Esses não são fixos e não cessam de mudar. Essa mudança, por sua vez, se dá segundo critérios ou configurações complexas em que dispositivos materiais e objetivos sociais impostos às subjetividades laboriosas são retrabalhados e reelaborados. Para ele, o uso de si nos atos de trabalho, como uso de si por si, traz a marca do que é para o homem a sua herança da vida.

Visando facilitar a compreensão, o autor exemplifica os propósitos contraditórios do operador, ao citar relatos: "eu faço o que me dizem". Esse mesmo operador se contradiz, afirmando que "jamais um trabalhador fica diante da sua máquina pensando: eu faço o que me dizem". Desse modo, "em qualquer grau que seja e no mesmo movimento de tomada de disposição parcial do uso heterodeterminado de si, o trabalho é sempre uso de 
si por si, recentramento do meio de trabalho ao redor de seus possíveis singulares" (SCHWARTZ, 2000a, p.42). Se há negociação da aceitação entre o que as condições de trabalho exigem e o uso de si que se está disposto a fazer, cada sujeito entra nessa cena com exigências diferentes. Sendo assim, como sugere a distinção entre trabalho prescrito e trabalho real, trabalhar de outro modo, então, já está sempre presente no "trabalhar como me dizem".

Vale enfatizar que as modalidades de uso de si remetem aos destinos individuais, às negociações entre a cena coletiva e o que a história produziu em cada um como marcas particulares. Desse modo, porque trabalha e se trabalha continuamente, cada sujeito desenvolve a si próprio e se usa em parte em função de sua história.

Nessa concepção, toda forma de atividade requer que variáveis sejam geridas, ou seja, toda atividade de trabalho é um debate entre normas antecedentes e recentradas (SCHWARTZ, 2005). As antecedentes estão associadas ao "uso de si pelos outros" enquanto as recentradas ao "uso de si por si". O autor remete esse debate ao "si", enquanto corpo e alma, seres de história e experiência. Gerir, portanto, é fazer escolhas, combinações, misturas entre esses dois tipos de normas. Gerir só é possível por causa dos valores, que no momento da ação orientam para se fazer essas arbitragens.

Antes de pensar em gerir o trabalho, é preciso, em primeiro lugar, pensar a atividade de trabalho como gestão, que significa a existência de confrontação entre as pessoas que trabalham com situações históricas, as dimensões singulares não vividas anteriormente e que precisam ser tratadas. Nessa história, existem as configurações do presente, ou seja, os eventos, incorporando-se em toda atividade de trabalho. Gerir, dessa forma, não é administrar aplicando regras e ordens, mas gerir emoções, gerir uma equipe (SCHWARTZ, 2005).

Pensar o trabalho como gestão é avaliá-lo como criação e produção de atividades, criação de si no processo dessa criação. Melhor dizendo: criação de si e do trabalho no processo do trabalhar. Gestão, por conseguinte, pode significar administrar tanto quanto gerir; não se restringe a administrar, governar, dirigir, controlar, como em geral o termo é compreendido e praticado. Gestão também significa reger, produzir, criar (MACHADO; BIANCO; PETINELLI, 2006).

A reflexão de Schwartz (in FIGUEIREDO et al., 2004) indica que toda gestão supõe escolhas, ponderações, critérios, certo engajamento. Nas situações de trabalho, a todo o momento ocorrem microescolhas, microdecisões que levam a uma adaptação indefinida, a uma vigilância sensorial, relacional e intelectual, à necessidade de modificações constantes de normas, regras e procedimentos que propiciem a própria realização das atividades (MACHADO; BIANCO; PETINELLI, 2006). Sendo assim, parafraseando Schwartz (2000a), todo trabalho já é gestão e essa gestão não é separável dos modos de gestão de si mesmo.

Na visão de Machado, Bianco e Petinelli (2006), o trabalhador, ao desenvolver sua atividade, constantemente faz opções, regulações, previsões, numa intensa atividade mental, que na maioria das vezes não é percebida por outros além dele mesmo, ou somente por aqueles que desenvolvem a mesma atividade. Ainda pode ocorrer de essa intensidade não ser percebida por ele mesmo, tornando-se um processo naturalizado, inerente à atividade. Dessa forma, segundo as autoras, na "rapidez" está inclusa a decisão a tomar, o agir e a realização da tarefa de acordo com as normas prescritas ou renormatizadas e ainda a existência de uma preocupação com o atendimento do objetivo daquela ação.

Como dito acima, há dificuldade, mas também necessidade de gerir o trabalho, já que as normas antecedentes não são apenas exigências e restrições; trazem também progresso para a espécie humana. Por outro lado, somente se pode gerir, governar o trabalho no desconforto, sem certezas nem receitas (SCHWARTZ, 2005). Gerir o trabalho dos outros é sempre aprender a "gerir as gestões", a gerir os diversos, e frequentemente, invisíveis debates dos outros com eles próprios. Essa atitude requer uma disponibilidade sempre renovada, custosa e difícil. Saber que se tem que gerir gestões muda tudo no exercício do governo do trabalho (SCHWARTZ, 2005). 


\section{Aspectos metodológicos da pesquisa}

A presente pesquisa tem como base os conceitos metodológicos utilizados pela abordagem ergológica, tendo como baliza o conceito do dispositivo a três polos apresentado por Schwartz (2000b). Esse dispositivo tem, inicialmente, o polo dos conceitos, que comporta materiais para o conhecimento, ou seja, o estudo da literatura disponível sobre o assunto. Em seguida, o polo das "forças de convocação e de reconvocação", que é o polo dos saberes gerados nas atividades de trabalho e que só pode ser revelado por meio da "interação" com os trabalhadores. $\mathrm{O}$ encontro fecundo entre os dois polos deve se reproduzir pela existência essencial de um terceiro: o das exigências éticas e epistemológicas, que contrariamente aos outros, não contém saberes préestocados ou investidos nas atividades.

Por conseguinte, optou-se por realizar um estudo de caso, que, conforme Godoy (1995b), caracteriza-se como um tipo de pesquisa qualitativa cujo objetivo é uma unidade que se analisa profundamente, por meio de exame detalhado de um ambiente, uma situação de trabalho e que não procura enumerar ou medir eventos. $\mathrm{O}$ estudo de caso envolve a obtenção de dados descritivos sobre processos interativos através do contato direto do pesquisador com a situação estudada.

Seguindo esses conceitos, a pesquisa foi realizada numa empresa de grande porte situada no Estado do Espírito Santo, aqui denominada Souple, pertencente a um grupo multinacional francês, que atua na área de fabricação de tubos flexíveis para exploração de petróleo em regiões marítimas. A escolha se deveu à facilidade de acesso por parte do pesquisador à empresa, assim como a existência de demanda pelo estudo das situações de trabalho por parte de trabalhadores e gestores de determinado setor de produção dessa organização. O referido setor é responsável por uma etapa do processo de fabricação dos tubos flexíveis - a camada zeta — que outorga ao tubo flexível resistência à pressão externa. Nesse setor, como em todos os outros da empresa, a prescrição está muito presente em normas, instruções de trabalho e procedimentos operacionais rígidos.

O setor estudado é composto de uma máquina principal com dois "skids" (viradores de bobinas de tubos: um de emissão do tubo com a camada anterior e outro de recepção do tubo depois de processado). Há dois bancos de bobinagem que desenrolam o fio de aço a ser aplicado no tubo, transferindo-o do "spool" que vem do fornecedor para as bobinas de fio alimentadoras da máquina principal. Para facilitar a compreensão, a figura 1, a seguir, apresenta o seu layout.

Figura 1: Layout do setor estudado

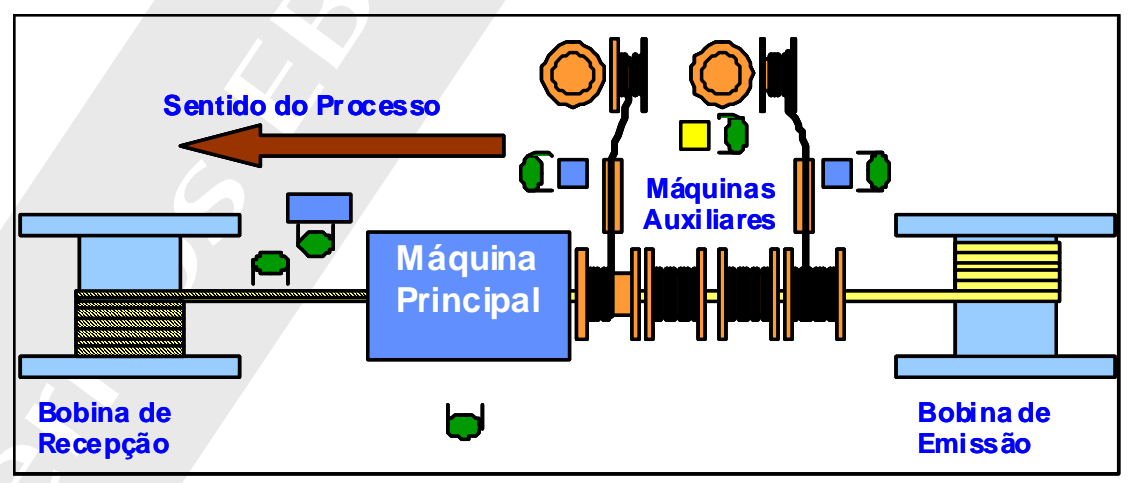

O quadro funcional do setor é composto de seis (6) trabalhadores por turno que, atuam em quatro (4) turmas de revezamento, além de um líder de fabricação, que trabalha em horário administrativo. Todos os trabalhadores são do sexo masculino, recebem salário fixo, sem remuneração variável ou ganhos por produtividade. A maioria possui curso técnico em mecânica concluído ou em conclusão. Quanto à idade, há um equilíbrio entre trabalhadores "antigos", mais experientes (alguns com até 18 anos de empresa nesta função) e "novatos", pois a empresa está em processo de expansão. O Quadro 1, a seguir, apresenta alguns dados relativos aos 
trabalhadores do setor estudado e mais adiante se faz uma descrição dos sujeitos/ trabalhadores diretamente vinculados ao estudo.

\section{Quadro 1: Perfil dos trabalhadores do setor estudado.}

\begin{tabular}{cccc}
\hline \multicolumn{4}{c}{ PERFIL DOS TRABALHADORES DO SETOR ESTUDADO } \\
\hline Idade & Tempo de Empresa & Escolaridade & Experiência Profissional \\
\hline Média de 29 & Média de cinco anos, & $70 \%$ dos trabalhadores possuem & $90 \%$ dos trabalhadores já trabalharam \\
anos, sendo & sendo que 35\% têm & curso técnico completo ou em & em outras empresas, no entanto apenas \\
que 60\% têm & cerca de um ano de & conclusão, 20\% possuem o & 35\% possuem sólida experiência de \\
até 26 anos. & empresa e 60\% tem & ensino médio e 10\% o ensino & indústria por terem trabalhado em outras \\
& menos que 3,5 anos. & fundamental. & empresas por mais de cinco anos. \\
\hline
\end{tabular}

Como forma de conhecer a história de vida dos trabalhadores individualmente, o que contribui para a compreensão das situações estudadas, apresentam-se alguns aspectos de seus relatos históricos, verbalizados pelos próprios trabalhadores no decorrer do período de acompanhamento das situações em campo, assim como durante as entrevistas. Entretanto, sabe-se das limitações desta breve biografia, pois a mesma não dá conta de todos os aspectos e riqueza de vida dos trabalhadores; contudo tem o objetivo de possibilitar uma aproximação com essas pessoas e com a realidade vivida na empresa, acreditando-se que isso possa enriquecer o ponto de vista analítico. Neste breve relato não se propõe ser isento, uma vez que a descrição tem o filtro do pesquisador com o olhar de quem trabalhava neste ambiente organizacional.

A presente pesquisa, como um todo, abordou cerca de trinta (30) trabalhadores que estavam presentes no setor de Espiralagem, como dito, divididos em quatro turmas de revezamento. No entanto, optou-se por apresentar aqui o histórico de vida dos mais atuantes no decurso da pesquisa, utilizando-se de nome fíctício para cada trabalhador apresentado, no intuito de preservar a sua identidade e respeitar a sua privacidade.

O operador chefe de processo Alfredo sempre esteve atencioso e participativo nos momentos em que fora solicitado. Ele era casado, 33 anos de idade e mais de 10 anos de empresa. Iniciou sua vida profissional em uma empresa de retífica de motores, onde foi operador de torno, o que, segundo ele, lhe proporcionou experiência em medições com paquímetro, o que é muito utilizado hoje no desenvolvimento de suas atividades. Saindo de lá, foi trabalhar em uma empresa terceirizada numa grande mineradora como ajudante geral. Após algum tempo, o seu irmão abriu um restaurante e ele foi trabalhar com o mesmo. Neste restaurante ele tinha o cargo de gerente, mas na realidade era um "faz-tudo": ajudava onde fosse necessário. Saiu do restaurante e foi trabalhar na Souple, onde, admitido como auxiliar, foi galgando promoções para operador e agora, operador chefe de processo. Ele era bem-humorado, um cara brincalhão e descontraído e devido a isto, possuía bom relacionamento com os demais operadores. Era considerado democrático, participativo, ensinava como fazer e era aberto e receptivo a sugestões, talvez por isto, a sua equipe fosse unida. Ele era o articulador de todas as confraternizações do setor, idealizava e organizava. Sabia delegar atividades para que todos pudessem contribuir e sempre que eram solicitados por ele a participar, faziam-no de bom grado.

O Leônidas fazia parte da equipe que trabalhava com o Alfredo. Ele era auxiliar de fabricação e atuava nas bobinadeiras. Era solteiro. Tinha 23 anos de idade e pouco mais de um ano de empresa. Nunca havia trabalhado em indústria. Concluiu o curso técnico em 2006. Possuía bom humor e tinha boa integração com a equipe.

Outro componente da equipe que trabalhava com o Alfredo era o Wilson. Ele era oficial de fabricação (operador) e atuava nas bobinadeiras. Tinha 23 anos de idade e um ano de empresa. Iniciou sua carreira profissional como menor aprendiz numa grande companhia siderúrgica, em um convênio com o SENAI no curso de elétrica geral, atuando no setor de lingotamento contínuo. Saindo de lá, foi estagiar em uma contratada da própria empresa, pois neste momento já estava na Escola Técnica Federal fazendo o curso de técnico em metalurgia. Nesta empresa atuava no escritório técnico, fazendo controles de manutenção e reformas de equipamentos. De lá foi para uma empresa de Tubos e Conexões como inspetor de qualidade, onde ficou durante dois anos. Após isto foi trabalhar em uma empresa contratada de uma grande mineradora para atuar na 
área operacional, lidando com os efluentes oleosos. Mais tarde, foi trainee de operação desta empresa, o que não lhe agradou e por este motivo optou por trabalhar na Souple. À época, estava cursando faculdade de Direito (era bolsista). Ele era bem-humorado, de bem com a vida, participativo e um pouco questionador. Gostava de dar sugestões e procurava aprender o trabalho, buscando entender o seu funcionamento. Era de família humilde e demonstrava anseios de crescer na vida. Tinha bom relacionamento com a equipe e era bem aceito pela mesma.

O Cláudio era o operador chefe de processo de outra turma. Ele era casado, tinha cerca de 40 anos de idade e mais de 12 anos de empresa. Antes trabalhou em uma oficina de usinagem. Não tinha formação técnica. Era introvertido, quase nunca sorria, aparentando até ser mal-humorado. Era considerado de difícil acesso e se mantinha à distância, evitando exposição. Isto prejudicava o seu relacionamento com os demais trabalhadores, resultando assim em reclamações. Em contrapartida, demonstrava bom conhecimento do processo e aparentava ser comprometido com a empresa (vestia a camisa). Normalmente era o operador que tinha a maior produtividade do setor, pois fazia tudo com muita agilidade e sem dar muita ênfase aos procedimentos de segurança, mas defendia os procedimentos operacionais, pois sua preocupação maior era com a produção.

O Izaque era o braço direito do Cláudio. Era o preferido dele dentre todos os trabalhadores do setor. Ele era oficial de fabricação (operador) e atuava na espiraladora. Era casado, tinha 26 anos de idade e pouco mais de um ano de empresa. Antes, trabalhou em uma prestadora de serviços de uma grande siderúrgica como mecânico. Ele possuía curso técnico em metalurgia. Literalmente "vestia a camisa da empresa", era daqueles que tudo estava bom, podendo até reclamar de algumas atitudes dos demais operadores, mas não da empresa. Demonstrava ser obediente e não era questionador. Possuía considerável vigor físico e fazia uso disto. Muitas vezes, tarefas que seriam realizadas por dois ou mais operadores, ele as fazia sozinho. Era um dos poucos operadores que gostava de trabalhar com o Cláudio, portanto a liderança não os separava, pois a recíproca era verdadeira.

Outro componente da equipe que trabalhava com o Cláudio era o Álcio. Ele era auxiliar de fabricação e atuava na bobinadeira. Ele tinha 33 anos de idade e sete meses de empresa. Era casado. Iniciou sua carreira profissional como almoxarife e depois foi trabalhar na área administrativa como auxiliar, chegando a ser chefe de departamento num escritório de uma empresa de construção civil. Em seguida, passou a ser bancário e logo após foi trabalhar em uma empresa fabricante de fertilizantes. Iniciou, nesta empresa, na área de faturamento e depois foi promovido a comprador, o que segundo ele foi muito estressante pela cobrança. Neste período fez um curso técnico em segurança do trabalho e foi trabalhar em uma prestadora de serviços na oficina de vagões de uma grande mineradora, atuando como técnico de segurança. Saiu de lá e foi para a Itália trabalhar em uma fábrica de vinhos como operário, onde passou dois anos. À época, estava concluindo o curso técnico em mecânica, mas já era formado em contabilidade e informática, além de segurança no trabalho. Era um aprendiz dedicado, procurava seguir os procedimentos e sempre estava à procura de ajudar alguém, pois "não corria de nenhum serviço". Era de bom relacionamento, estava bem integrado à equipe e demonstrava contentamento por estar trabalhando na empresa.

O Dalmo era o operador chefe de processo da terceira turma. Ele tinha 40 anos de idade e mais de 10 anos de empresa. Era casado. Sempre teve empregos de longa duração. Trabalhou cinco anos em uma empresa de conexões no setor de qualidade. Começou como controlador e foi mais tarde promovido a líder de equipe. Depois disto trabalhou em uma fábrica de granitos como operador, onde ficou por mais de quatro anos. A empresa fechou e aí foi trabalhar na Souple, como auxiliar, sendo promovido à oficial e então, a operador chefe de processo. Possuía formação técnica em mecânica e demonstrava bom conhecimento do processo. Aparentava ser sério, introvertido, mas na realidade era bem-humorado e de bom relacionamento com a equipe, sendo de fácil acesso e tendo boa aceitação de todos.

O Michel era um dos integrantes da equipe que trabalhava com o Dalmo. Ele era auxiliar de fabricação, atuava na espiraladora, tinha 24 anos de idade e pouco mais de um ano de empresa. Trabalhou antes em uma empresa terceirizada de uma grande siderúrgica, atuando na área de manutenção. Concluiu o curso técnico em 2006. Era solteiro, surfista e tinha um jeito despojado de ser. Era bem-humorado e possuía boa integração com a equipe. 
O Walace era outro componente da equipe que trabalhava com o Dalmo. Ele era auxiliar de fabricação e atuava nas bobinadeiras, mas depois foi deslocado para a espiraladora. Tinha 25 anos de idade e pouco mais de um ano de empresa. Era solteiro. Veio para Vitória quando seu pai foi desligado de uma empresa estatal. Devido às necessidades, ingressou no mundo do trabalho aos 16 anos, trabalhando como auxiliar numa farmácia. Depois foi trabalhar em uma serralheria, sendo ajudante geral, onde ficou até completar 22 anos (até este período ele só havia concluído o ensino fundamental). Em seguida, foi trabalhar em uma empresa como vendedor, atendendo ao pequeno varejo (comércios em geral). Na nova área, foi influenciado a retornar aos estudos. Fez um supletivo e ingressou em um curso técnico em mecânica, que foi concluído em 2006. Durante o curso, estagiou na oficina de vagões de uma grande mineradora. Encerrado o seu estágio, ele foi trabalhar em uma contratada de uma grande siderúrgica mineira na área de manutenção. Durante este período, montou um pequeno negócio. Saiu da empresa para se dedicar ao negócio próprio, mas o mesmo não deu resultado satisfatório. Então buscou emprego e foi trabalhar na Souple.

O Walace demonstrava interesse e comprometimento. Era questionador e não aceitava facilmente orientações, pois segundo ele mesmo, "para fazer uma tarefa de bom grado tem que entender o motivo e concordar com ele". Era bem-humorado e fazia brincadeiras com todos (ele criou uma brincadeira de colar as coisas no capacete ou nas costas dos outros operadores sem que eles vissem; era uma brincadeira simples, mas quase todos se divertiam com ela; qualquer um que tivesse algo preso no capacete era motivo de chacota dos demais companheiros, tudo em harmonia, com a complacência e participação da maioria). Ainda, era bem relacionado e articulado com os demais, pois tinha facilidade de comunicação, boa oratória e argumentação. Era criativo e ativo, sempre procurando fazer algo diferente dos padrões, procurando uma forma mais fácil de executar as tarefas. Aparentava ter algumas limitações técnicas, especialmente no que se referia a cálculos.

O Clayton era o operador chefe de processo da quarta turma. Ele tinha 37 anos de idade e mais de 10 anos de empresa. Era casado. Formou-se como técnico aos 15 anos pelo SENAI e começou a estagiar em mecânica logo em seguida. Depois do estágio, foi para uma empresa que fabricava equipamentos pesados para prefeituras (betoneira, máquinas de fazer tijolos, etc.). Trabalhou 10 anos nesta empresa, iniciando como técnico e depois, segundo suas próprias palavras, "tornou-se o homem de confiança do dono da empresa", respondendo por toda parte técnica, orçamentos, projetos e execução. Neste período ele era atuante no movimento sindical. Ainda nesta empresa, idealizou e desenvolveu uma máquina automática de fabricar tijolos e devido a isto foi convidado para trabalhar em um projeto para desenvolvimento de um equipamento de corte de árvores, uma parceria entre duas empresas. No entanto, por causa de um desentendimento, ele foi demitido. Passou a se dedicar à vida religiosa, foi estudar teologia e então era pastor de uma igreja evangélica, onde desenvolvia um projeto social junto a uma comunidade carente. Com o nascimento do filho retornou ao mercado de trabalho, foi quando começou a trabalhar na Souple.

O Francisco era oficial de fabricação e atuava na espiraladora na equipe do Clayton. Tinha 23 anos de idade e pouco mais de um ano de empresa. Ele era casado. Iniciou sua vida profissional aos 12 anos, quando ingressou no SENAI para fazer um curso de mecânica geral, sendo bolsista. Após dois anos, quando concluiu o curso, começou a estagiar numa grande mineradora. Ao término do estágio, ainda com 15 anos de idade, trabalhou por três anos em uma oficina de usinagem como torneiro. Ao completar 18 anos, foi trabalhar como mecânico de manutenção em uma empresa terceirizada de uma grande siderúrgica. Durante todo este período, ele continuou estudando e concluiu o curso técnico em mecânica. Neste ínterim, iniciou, juntamente com mais dois sócios, uma empresa de manutenção de pontes rolantes (equipamento de elevação de cargas). Entretanto, não obteve sucesso. Todavia, ele não desistiu de ter o seu próprio negócio, pois ainda buscava alternativas para viabilizar a sua empresa de manutenção. Ele era bem-humorado e benquisto por todos. Sempre procurava alternativas para realizar as tarefas rotineiras, questionando e dando sugestões, mas não se indispunha com ninguém, pois mesmo quando contrariado, fazia o que the era solicitado, procurando argumentar com bom senso. Era considerado um profissional maduro.

O Evandro era outro componente da equipe que trabalhava com o Clayton. Ele era oficial de fabricação e também atuava na espiraladora. Era solteiro. Tinha 24 anos de idade e três de empresa. A Souple era o seu primeiro emprego. Em 2007 concluiu o curso técnico em mecânica. Falava que queria estudar para poder crescer na vida. Buscava se antecipar às necessidades, mas era um pouco desajeitado, transparecia possuir 
dificuldade com cálculos e trabalhos manuais. Havia atividades que ele gostava de fazer e prontamente se candidatava a realizá-las, mas havia outras de que não gostava e notavelmente se omitia para não participar de sua realização (principalmente atividades de montagem e desmontagem). Era bem-humorado, falante, de bom relacionamento com a equipe e de agradável convivência. Não se podia dizer que fosse criativo, nem questionador, mas gostava de entender o porquê das tarefas, porém quase nunca as questionava.

O Sílvio era outro oficial de fabricação que compunha a equipe que trabalhava com o Clayton, atuando nas bobinadeiras. Ele era casado, tinha 38 anos de idade e mais de 12 anos de empresa. Não possuía formação acadêmica, mas era uma referência para todos, um dos trabalhadores mais antigos da área, era tranquilo e atencioso com os novatos. Gostava de fazer as coisas conforme determinavam os procedimentos, e segundo ele mesmo, procurava "trabalhar corretamente". Antes de trabalhar na Souple, trabalhou em lojas e pequenas oficinas.

O Carlos era o líder de fabricação e responsável por todo processo de espiralagem. Ele tinha 35 anos de idade e mais de 15 anos de empresa. Era casado. Possuía curso técnico e entrou na Souple como auxiliar de fabricação. Obteve promoções, sendo oficial de fabricação e operador chefe de processo, passando, inclusive, por outros setores da empresa. Ele tinha espírito de liderança, era bom negociador e compreensivo com os seus subordinados, no entanto, era direto e objetivo. Sabia da sua responsabilidade, mas apesar de "vestir a camisa da empresa", não compartilhava com todas as políticas adotadas pela mesma (certa vez se recusou a ir a um churrasco pago para os líderes e operadores "chave", como forma de protesto e solidariedade a todos os outros trabalhadores, pois segundo ele, "as conquistas são resultado do trabalho de todos, não de uma elite"). "Colocava a mão na massa" quando era necessário, e estava sempre disponível para colaborar, pois era bom planejador e executor. Era bem-humorado e era benquisto pelos operadores, contudo, notava-se uma barreira, certo distanciamento entre chefe e subordinado.

Por fim, vale ainda apresentar o autor da presente pesquisa, uma vez que na qualidade de profissional da empresa à época, também foi participante. Tinha 31 anos de idade e mais de 10 anos de experiência profissional em indústrias. Ele era casado, graduado em Tecnologia Mecânica e com especialização em Engenharia de Produção. Iniciou sua vida profissional aos 15 anos como office boy numa empresa produtora de celulose e foi galgando promoções, passando por auxiliar de segurança do trabalho a operador industrial em diversas áreas desta empresa, na qual ficou por 10 anos. Após concluir o curso de especialização, obteve uma oportunidade profissional e foi trabalhar numa empresa de alimentos como engenheiro de produção, passando por todo o processo produtivo e permanecendo nesta organização por 6 anos. Após este período, foi trabalhar na Souple como engenheiro de produção, na qual permaneceu por cerca de um ano. Pode-se acrescentar que o interesse pelo tema em estudo se deve a inúmeros trabalhos desenvolvidos nestes anos atuando como engenheiro de produção, fazendo adequações de layout, balanceamento de linhas e descobrindo novos métodos de trabalho, percebendo-se, durante estas situações, a importância da atuação do homem frente às mudanças propostas.

Neste sentido, buscando-se compreender o não visível no desenvolvimento das atividades de trabalho e no sentido de estar presente, foi usada, nesta pesquisa, inicialmente, a observação participante como método para a produção de "dados". Buscou-se "interagir" com os trabalhadores e o ambiente de trabalho, pois se entendia que, sendo o intuito "compreender" o trabalho, era preciso observá-lo onde ele ocorre, interagindo com os trabalhadores, perguntando-lhes o que há a fazer e como o fazem (GODOY, 1995a). Tendo como finalidade cobrir essas premissas, seguindo o rigor de um método, lançou-se mão de um período de aproximadamente quatro meses de imersão total do pesquisador junto aos trabalhadores. Nesse período, o pesquisador esteve presente na área estudada cerca de seis horas diárias, fazendo acompanhamento in loco nos turnos matutino, vespertino e noturno e relatou os acontecimentos em um diário de campo, sempre considerando os fatos e as condições do ambiente, tanto objetivas quanto subjetivas.

Buscou-se ler todos os procedimentos operacionais em vigor, como normas de segurança e instruções de trabalho aplicadas ao setor estudado bem como informações técnicas a respeito do processo em si, intentando apreender necessidades e variáveis operacionais aplicáveis a essas máquinas. O levantamento documental resultou em leitura e interpretação de mais de 50 documentos referentes à prescrição das atividades. Buscou-se, 
com a atitude, esclarecer o contexto e as condições nas quais os dados estavam sendo produzidos, confrontando-se o que em tese deveria ser feito com o que realmente era feito, para evitar atribuir-lhes uma significação que não tinham.

Optou-se ainda por realizar atividades de validação e análise das percepções obtidas durante o período de acompanhamento. Uma alternativa viável para transparecer aos trabalhadores o andamento da pesquisa foi buscada, pois segundo Godoy (1995b, p.27), "no estudo de caso, o ideal é que a análise esteja presente durante os vários estágios da pesquisa, pelo confronto dos dados com questões e proposições orientadoras do estudo". Para tanto, foram realizadas quatro reuniões, uma com cada turma, para discutir com o grupo as percepções que até aquele momento haviam sido produzidas e registradas.

Como forma de ampliação do conhecimento, foram feitas entrevistas semiestruturadas e individuais com o líder de produção, três operadores chefe de processo, três operadores da máquina principal e dois operadores das máquinas auxiliares, totalizando nove (9) entrevistas. Todas elas gravadas e posteriormente transcritas, ou seja, mais de 10 horas de gravação. A análise dos "dados" adotou a utilização de métodos indiretos de interpretação e análise para todo o material obtido, buscando compreender os sentidos que os trabalhadores dão ao seu trabalho e às suas falas quando reproduzem nelas o seu trabalho e o contexto de sua realização. Por isso entendeu-se como importante conhecer e apresentar cada um deles, os "gestores" do trabalho no setor da empresa investigado.

É importante dizer que a opção metodológica influencia na análise dos dados e em como ela é apresentada. Desta forma, a partir do próximo item busca-se valorizar o discurso dos sujeitos e as apreensões por eles singularizadas.

\section{Análise das situações de trabalho}

As situações de trabalho são compostas de histórias, experiências de vida de cada trabalhador ali presente e dos que por ali já passaram (SCHWARTZ, 2003). Por esse motivo, devem ser analisadas no seu contexto histórico, pois as experiências vividas influenciam na construção das gestões do presente. Para tanto, a busca por conhecer a história de vida dos trabalhadores individualmente, assim como o contexto organizacional no qual estão inseridos, contribuiu para a análise e a compreensão das situações estudadas.

No ambiente de trabalho, o "fator competitivo" esteve presente, ativo ao longo do período de interação, mesmo que não de maneira explícita. Notou-se competição entre os trabalhadores (individualmente e entre as turmas dos turnos de revezamento), devido à existência de um contexto sócio-organizacional que leva os trabalhadores a agirem assim.

Esta competição pôde ser percebida na pesquisa em muitos momentos. Por exemplo, na forma de uma comemoração explícita, por um dos trabalhadores quando da execução de uma tarefa bem realizada e, em contrapartida, pela negação deste feito e/ou pela busca de um defeito por parte dos demais trabalhadores. Podese citar o fato ocorrido quando o operador Francisco comemorou o resultado obtido ao realizar a tarefa de fixação de uma manchete (que é uma terminação do tubo que serve como acabamento e ponto de fixação para movimentação do mesmo).

Esta tarefa era realizada ao final da produção de um tubo e seguia o seguinte procedimento prescrito: primeiro colocava-se a manchete na ponta do tubo e marcava-se o fio para cortá-lo, a fim de que o mesmo se encaixasse nas saliências da manchete, de modo a ficar fixo com segurança. Após marcar e cortar o fio, o Francisco recolocou a manchete na ponta do tubo e constatou que a mesma se encaixou perfeitamente, sem folgas ou interferência, ou seja, tanto a marcação quanto o corte foram precisos. Imediatamente ele sugeriu a todos que fossem ver com que perícia executara tal tarefa. No entanto, quando se achegaram para ver, o que se podia ouvir eram frases de negação: "- eu sempre faço assim", "- esta é a primeira vez que você consegue fazer isto?" e outras mais. Estes fatos mostraram-se comuns em todos os turnos, pois os operadores não se sentiam à vontade em elogiar o trabalho do outro; a competição parecia estar presente nas "entrelinhas" do contexto produtivo e permeando as relações de trabalho. 
$\mathrm{Na}$ competição entre turmas/turnos, um fato ilustrativo aparecia no momento da escolha dos insumos a serem utilizados nas atividades de trabalho. Quando os trabalhadores "carregavam" os materiais que eles mesmos utilizariam na produção, procuravam selecionar os que tinham poucos defeitos. Quando, no final do turno, carregavam materiais que seriam utilizados pelo turno subsequente, escolhiam os que tinham maior quantidade de defeitos, pois assim, segundo eles mesmos, dificultariam a produção do turno seguinte e reduziriam a chance de terem que processar um material com muitos defeitos no próximo dia. Isso era renormatização do trabalho e realização de trabalho real, estavam desenvolvendo estratégias de ação baseadas nos valores destes sujeitos e não de outros e gerindo suas atividades de trabalho. Encontrou-se aqui um exemplo claro da dificuldade em se gerir, na verdade, "a gestão do trabalho realizado".

Essa ocorrência foi um fato notório nas turmas, mesmo não sendo o procedimento prescrito. Esse assunto também foi abordado nas reuniões de validação e análise dos "dados". Os trabalhadores se sentiam incomodados com tal fato, mas, mesmo assim, o faziam. No decorrer das reuniões, pôde-se acordar, partindo da solicitação dos próprios trabalhadores, que tal prática fosse abolida e que todos passassem a carregar os insumos com base na ordem de chegada dos mesmos no setor e não mais com base no número de defeitos. Essa mudança acordada em grupo resultou numa transformação na realização das atividades; uma das perspectivas transformadoras das situações de trabalho defendida pela análise ergológica.

É interessante observar, ainda, que a competição fazia parte da busca pela expansão do controle sobre os processos de trabalho, o que pôde ser observado em diversas situações e ficou evidenciado na fala do operador Francisco ao se referir à intensificação de seu trabalho. Segundo ele, "a máquina tem metas para cumprir e essas metas são cobradas. São cobradas do nosso gerente, o nosso gerente cobra do nosso líder e o nosso líder cobra da gente". Estabelecia-se, assim, uma racionalidade como uma "cadeia de pressão" e se podia falar em indução da competição, buscando a máxima produtividade e, dando margem à busca de soluções por meio da criação e do uso de si.

Essas condições impunham aos trabalhadores uma pressão, no entanto estes não tinham domínio sobre todos os fatores ou recursos intermitentes e inerentes aos processos de produção, mas ora eram responsabilizados como se tivessem. Deste modo, os trabalhadores se viam em uma "dramática" (Schwartz, 2000a), ou seja, numa encruzilhada que dizia respeito às variabilidades dos processos e a negação das possibilidades de falha. Resultando assim na obrigação de acerto e cumprimento dos objetivos pré-estabelecidos, pois, segundo o operador Francisco, "quando a gente erra tem que correr atrás para não errar mais e tentar consertar o erro. No entanto, quando acerta, você está fazendo a obrigação."

A equipe, nas reuniões, reconheceu que havia espaço para melhoria, mas demonstrando ciência de suas necessidades e capacidades, insistiu também na contrapartida da empresa em disponibilizar recursos suficientes e eficientes para auxiliar nas tarefas, pois segundo os operadores, a cobrança era intensa, mas não havia recursos necessários:

[...] algumas vezes nós estamos ganhando tempo na execução das tarefas, mas perdendo todo este tempo e até mais na preparação. Por exemplo, reduzimos o tempo no processo de solda de 90 para 60 min., mas já presenciei algumas vezes a linha parar para solda, sem ter disco de corte. Então o operador vai até o almoxarifado requisitar um, trocar o que está na esmerilhadeira, e depois começa o processo de solda. Com isto já perdemos mais de uma hora, mais que o tempo que reduzimos. Portanto, não adianta tentarmos melhorar os procedimentos se não conseguirmos antecipar as necessidades. Temos que trabalhar preventivamente (o líder CARLOS).

O trabalhador no caso falava como equipe, estava "vestindo a camisa da empresa", defendendo o compromisso dos trabalhadores com o trabalho e destacando que a renormatização do trabalho dependia das condições prescritas, que vão além das descrições das tarefas, inclui as condições organizacionais dadas para a realização do trabalho. O uso de si por outros - conforme analisado anteriormente - envolvia claramente estas condições sócio-organizacionais. Ainda para enriquecer as análises:

[...] muitas vezes parece que a gente não quer fazer as coisas, mas não é isso que acontece. Quantas vezes a gente já pediu uma máquina de solda nova? Não temos. Quando a gente precisa, tem que sair 
pedindo emprestado aos outros. Muitas vezes, uma solda que demoraria cerca de vinte minutos a gente leva quase uma hora só para conseguir uma máquina emprestada. Ai atrasa tudo e parece que a gente fez corpo mole, mas não é isso. Entendo que a empresa tem que propiciar condições mínimas para nós. Condições mínimas não, condições plenas, as melhores condições possíveis. Se tivermos boas condições, poderemos realizar um bom trabalho (SÍLVIO, operador da bobinadeira).

O estado de cobrança sobre os trabalhadores os obrigava a estarem em estado frequente de alerta. Por inúmeras vezes foi observado que, ao menor barulho, ao menor sinal, o operador se via numa situação de alerta máximo, buscando formas de se antecipar, resolver uma situação de problema que simplesmente ainda não existia, mas que para ele poderia ser um sinal de perda de produção futura. Tratava-se de se realizarem ponderações, engajamento. Era a busca pela antecipação, na visão ergológica o trabalho mental já estava se processando e a gestão da atividade havia iniciado (SCHWARTZ, 2000a; SCHWARTZ in FIGUEIREDO et al., 2004).

Além dessa condição de alerta constante, ocorriam ainda, a todo tempo, novas demandas e a incorporação de tarefas que antes não faziam parte das responsabilidades dos trabalhadores, aumentando a intensidade, pressão e cobrança do trabalho. Nesse sentido, surgiam necessidades de adequação do processo ou nova diretriz quanto à sistemática já utilizada, resultando em renormatização das normas antecedentes, pois a realidade do trabalho se apresentava distante do prescrito.

Esse fato pôde ser registrado em momentos específicos, como na troca de turnos, onde o líder Carlos conversava com dois operadores chefes de processo, Clayton e Cláudio, orientando-os a respeito de alguns parâmetros do tubo que iriam produzir. Tratava-se de um tubo novo, com alguns parâmetros diferentes e específicos - coeficiente de resistência da solda elevado e não poderia conter solda nos primeiros 30 metros do tubo; uma característica incomum nos tubos produzidos, específica daquele projeto. Clayton disse que as informações não estavam contidas na ficha técnica da linha de produção - documento principal onde estava, ou pelo menos deveriam estar, parâmetros e informações para a produção de uma linha. O líder Carlos contraargumentou:

[...] eu sei, o pessoal da Qualidade vacilou, mas a gente poderia ter perguntado sobre isto. A partir de agora, em toda linha, nós devemos perguntar sobre o coeficiente de solda e a questão de ter soldas nos primeiros metros. Podem ir acostumando, pois acho que isto será uma constante de agora em diante.

O operador chefe Cláudio tomou partido e se manifestou: “[...] agora teremos que vigiar também o trabalho da Qualidade? Acho que isto deve vir de lá". O líder prosseguiu: "A responsabilidade é deles, mas a gente tem a obrigação de verificar. Se eles esquecerem e a gente fizer errado, quem dança somos nós. É a gente que terá que refazer tudo de novo." O operador chefe Clayton novamente se manifesta: "A partir de agora, então, nós teremos que desconfiar de tudo! Teremos que verificar tudo!" Pode-se imaginar a relação dos operadores com o trabalho nessa situação? A ficha técnica, que para eles era o guia, agora deveria ter sua veracidade questionada. Dessa forma, a situação ficou mais difícil, o que pôde ser percebido pelas falas dos operadores chefes ao final da conversa. As atividades de trabalho seriam, por eles, renormatizadas, ou seja, a gestão da atividade se iniciava com os operadores e eles realizavam as antecipações necessárias para realizá-la.

Pôde ser percebido aqui que a ofensiva pela produtividade estava cada vez mais presente, intensificando os ritmos de trabalho, o que resultava em condições cada vez mais adversas para o trabalhador, muitas vezes tratado pela organização como uma "máquina do processo produtivo". A ele era requerido estar atento a todas as possibilidades e demandas, sendo necessário gerir as variabilidades que o processo produtivo poderia trazer consigo, mesmo não tendo domínio sobre essas e sobre as condições das quais dependia o resultado do seu trabalho. Cabe destacar as dificuldades que esse trabalhador enfrentava no decurso de suas atividades, na tentativa de gerir o trabalho e 'dar conta' de uma atividade complexa e singular, requerendo que ele se envolvesse, interagisse e resolvesse; ou seja, solicitando-lhe integralmente, requerendo-se dele os usos de si. 


\section{As interações dos trabalhadores com o seu trabalho}

Buscando atender às demandas emanadas pelos atuais processos de trabalho, os trabalhadores necessitam se adaptar, ou melhor, se reconstruir a cada dia, buscando melhor desenvoltura frente às necessidades que lhes são requeridas. Conforme abordado anteriormente, ao longo de sua existência, eles inventam novas maneiras de pensar e agir sobre eles mesmos, assim como sobre o ambiente que os cerca (NOUROUDINE in FIGUEIREDO et al., 2004).

Os trabalhadores trazem consigo conhecimentos historicamente consolidados que serão agregados a todos da equipe, pois para eles o uso de si está integrado a como realizar a atividade. Esses conhecimentos podem não ser de uso específico da atividade que ora se realiza, mas provenientes de experiências passadas e podem emergir quando há necessidade de resolução de problemas. Esses são saberes práticos por eles incorporados que fluem quando solicitados pela atividade.

Focando-se uma situação real, a "linha" estava apresentando dificuldade de operação desde uma sexta-feira. Iniciou-se a produção de um tubo, produto novo, constituído de determinada matéria-prima nova. Durante todo o final de semana, os trabalhadores buscaram soldar uma fita de aço (para emendá-la) e não houve êxito. $\mathrm{O}$ "clima" entre os operadores já estava pesado, pois haviam tentado todos os recursos conhecidos até aquele momento, desde variar os ajustes da máquina de solda (corrente elétrica, velocidade de solda, quantidade de gás inerte) até trocar a botija de gás (suspeitava-se que o mesmo pudesse estar contaminado). Diversas maneiras de realizar a atividade foram tentadas, não obtendo, no entanto, êxito.

Com um espírito de total frustração, o engenheiro de solda praticamente "jogou a toalha". Era possível notá-lo completamente desolado, sem rumo. O seu semblante estava carregado tanto pelo cansaço, afinal, foram quatro dias de mais de doze horas diárias "de luta" com a máquina de solda, quanto com o resultado negativo de suas investidas para a resolução do problema. Após várias tentativas infrutíferas, um operador novato, com pouco mais de um mês de empresa, relatou que trabalhava numa empresa de calçados e que quando eles não conseguiam "soldar" o couro para os calçados, inclinavam a emenda, o que facilitava o processo de soldagem. Ninguém concordou com a idéia em princípio, pois não se viu consistência teórica na proposta. Tendo o mesmo insistido e como se estava praticamente sem outro caminho a trilhar, seguiu-se a sugestão, mesmo considerando-a pouco provável para a resolução do problema.

O efeito da ação, para a surpresa de todos, foi extraordinário. O procedimento de soldagem utilizado na fábrica é conhecido como soldagem de topo, pois une as duas extremidades da fita em corte perpendicular $\left(90^{\circ}\right)$ ao comprimento longitudinal. No caso específico, as extremidades foram cortadas inclinadas (conforme orientação do operador novato) em cerca de $55^{\circ}$, procedendo com a solda. Resultado: a solda ficou boa na primeira tentativa. Notava-se, então, o contentamento estampado no rosto do operador que deu a sugestão e, em contrapartida, o ar de descrença do engenheiro de soldas. Afinal, ele era uma pessoa qualificada, especialista em solda, trabalhava há anos com isso, fez mestrado em materiais, sendo teoricamente, a maior autoridade local no assunto. Um operador que acabara de entrar na empresa, sem a mesma formação e sem experiência em processo metal-mecânico, mas que trabalhara numa indústria de calçados, obtendo assim saberes, experiência prática, vivência do trabalho real com associação de diferentes modos de trabalhar, deu uma sugestão inédita e para todos ali pouco provável, mas que para ele era algo comum em seu trabalho anterior e que sempre funcionava, tendo sido, com isso, resolvido o problema. É o terceiro pólo em ação, o reconhecimento mútuo dos saberes teórico e prático.

Nada obstante, o trabalhador no seu ato de trabalho estava presente, buscando algo que lhe agregasse valor. Ele não buscava somente atingir as metas e os objetivos estabelecidos, mas também buscava saciar seu desejo de realização, buscava sua própria satisfação em virtude das vitórias alcançadas. A fala do operador Francisco durante sua entrevista corroborou esta idéia:

[...] Muitas vezes, você dar uma solução para um problema gera uma satisfação também, uma satisfação própria. Você vê um negócio agarrado lá e toma uma decisão que dá certo, você fica feliz. Você não precisa sair espalhando para todo mundo. Mas você fica feliz, porque você resolveu um 
problema. Aquilo ali gera uma experiência para você, gera uma bagagem. Aquela situação ali não vai te preocupar mais, não vai te pegar mais. Quando ela aparecer de novo, você já sabe o que fazer.

A importância da experiência em si veio à tona: aprender com as situações vividas e criar história por meio das decisões tomadas. Salientou a importância do fator humano no trabalho e corroborou o pensamento de Schwartz (1998) quando aborda os ingredientes da competência. Para o autor, a eficácia na realização do trabalho está cerceada por teoria e prática, assim como a interação entre as duas, que resulta na renormatização das normas antecedentes, culminando na ação transformadora do trabalho. Os trabalhadores, ao realizarem seu trabalho, adquirem saberes, usam-no, transformam-nos em saberes práticos, adquirem novos saberes, e como resultado desses novos saberes, recriam seus modos de trabalhar e os implementam, transformando-os; fazendo associações entre idéias e ações, entre teoria e prática, agindo, portanto, na renormatização de suas atividades e do meio.

\section{0 efetivo ato de trabalhar}

$\mathrm{O}$ ato de trabalhar traz consigo muitas contradições, dentre as quais a busca pela satisfação pessoal, que pode ser alcançada por meio do atingimento de metas e objetivos pré-estabelecidos frente às insatisfações geradas pelas prescrições das tarefas. Isso ocorre porque muitas vezes os trabalhadores se veem constrangidos a executar tarefas que para eles nada acrescentam às suas funções. As prescrições remetem ao primeiro polo de modo isolado, ao da valorização dos saberes teóricos. Na verdade, muitas tarefas são vistas como verdadeiros empecilhos, atrapalhando o bom andamento do seu trabalho.

Pôde-se notar, consequentemente, que nem sempre era possível ou preferível cumprir os procedimentos, pois, de acordo com os próprios trabalhadores, quando entrevistados, inúmeras vezes optava-se por não seguir o procedimento para se atingir a produção requerida. Havia inúmeras situações onde isso acontecia, não por uma insubordinação ao procedimento prescrito, mas pela imposição dos processos de trabalho ao trabalhador, que, dado às variabilidades situacionais, via-se em dificuldade, na difícil decisão de cumprir ou não o procedimento, tendo em vista a obtenção - ou não — das metas de produção. Nessas situações se exprimiam as dramáticas do uso de si dos trabalhadores.

Essa condição pôde ser entendida pela fala do operador chefe Alfredo, ao executar a tarefa de proteger uma bobina com tubo espiralado:

[...] se eu ficar esperando o empilhadeirista, vou demorar muito e meu negócio é acabar logo isto para colocar a máquina para rodar, pois não posso ficar esperando tanto tempo. Deste modo, gasto uns 30 minutos. Se for esperar a empilhadeira, vou gastar umas quatro horas. Depois como é que eu justifico todo esse atraso? Adianta falar que estava seguindo o procedimento? Eles aceitam isto? Não, eles querem é ver a máquina rodando. Não tem jeito, temos que produzir.

Dessa forma, os trabalhadores assumiam o que "devia ser feito" do jeito que julgavam mais conveniente e prosseguiam com a operação independente do procedimento, pois ficavam entre duas determinações não congruentes: a cobrança da execução do procedimento e a realização da produção requerida. Tratava-se de realizar escolhas, gerir, conforme exposto anteriormente (SCHWARTZ, 2005). Como as duas alternativas não eram possíveis simultaneamente, deviam optar por qual caminho trilhar e objetivo atingir: cumprir o procedimento ou entregar a produção no tempo requerido.

Outra questão estava relacionada às variações, às muitas variabilidades implícitas nos processos de trabalho. Variáveis de todos os tipos: características pessoais distintas; variação no processo físico (equipamentos, materiais); novas demandas, etc., que o procedimento, em sua racionalidade, não consegue prever em todas as suas possibilidades e diversidades. Ao se acompanhar um ajuste para o início da produção de um tubo, pôde-se constatar solicitações variáveis na fala dos operadores quando o operador chefe Alfredo ensinava aos mais novos como realizar o ajuste inicial da máquina. Ao ser questionado se todas aquelas medidas não estariam na ficha técnica, que é o procedimento formal, ele respondeu: 
No procedimento tem, mas ler no papel é uma coisa, fazer aqui na prática é outra. [...] Na teoria dá para fazer tudo calculando, mas na prática estes valores são só referência, o ajuste mesmo é no olho, pois tem que verificar o alinhamento do fio. Então, não adianta saber o que deve ser feito, tem que saber como fazer e porque está fazendo. A ficha técnica vem com todos os parâmetros especificados, mas se a GPR [camada anterior do processo] vier com diferença, pois eles consideram o diâmetro médio, a gente tem que ajeitar aqui no olho. E isto acontece só todo dia, pois é difícil vir igual. Na verdade, nunca vem igual durante todo o tramo. Imagina se eles conseguem a mesma medida em um quilômetro de tubo? Isso é impossível! Então a gente vai ajustando aqui de acordo com o processo.

Os eventos citados pelo operador chefe Alfredo permeavam as situações de trabalho vivenciadas por ele e exigiam do mesmo, em conformidade com o exposto por Schwartz (1998), competências no sentido de conhecimentos adquiridos anteriormente frente aos usos de si na práxis. Exigiam o entrecruzamento de um conhecimento teórico e prático das atividades de trabalho, assim como a abertura para novas demandas (ainda não vividas) e a implementação das renormatizações que o trabalho the imprimia como referência. Essa exposição demonstrou que o trabalho nunca é igual, nunca é o mesmo, que os usos de si são fruto de um julgamento de valores e de histórias vividas, num processo de trabalho dinâmico e em constante mutação.

\section{Trabalhar é fazer usos de sl}

Conforme abordado anteriormente, segundo Schwartz (in FIGUEIREDO et al., 2004), toda situação de trabalho pressupõe arbitragens, escolhas, ponderações, critérios, hierarquização de atos, objetivos e valores em nome dos quais essas decisões se elaboram. Dessa forma, todo trabalho é sempre uso de si, uso dramático de si: uso de si por outros e uso de si por si (SCHWARTZ, 2000a).

Esse uso que se faz de si, conforme já exposto, não é estático, fixo, mas está em incessante mudança, segundo critérios ou configurações complexas onde os dispositivos materiais, os objetivos sociais impostos às subjetividades laboriosas são sempre retrabalhados e reelaborados. Por outro lado, as formas de uso de si remetem também aos objetivos individuais, à vida, às suas negociações de prioridade, às suas necessidades, à sua busca pela contrapartida, que é sempre particular, negociações subjetivas entre o comum ao grupo, o coletivo e o que a história produziu em cada um individualmente.

Consequentemente, o trabalhador, no ato de trabalhar, se reconstrói continuamente, pois cada um se desenvolve e usa uma parte de si próprio em função das demandas emanadas pelo contexto a que está exposto. Ou seja, no uso que se faz de si, além de se buscar uma contrapartida, um retorno esperado, esse uso reescreve a história desse indivíduo particularmente, proporcionando-lhe novas capacidades adquiridas que logo também serão empregadas no desenvolvimento de suas atividades, numa tendência a usar de si para recompor o mundo à sua volta.

Dessa forma, os trabalhadores, no ato de trabalho, evocavam-se por inteiro na busca de novas alternativas para a realização do seu trabalho, renegociando suas ações. Negociações que podiam ocorrer consigo mesmo e, muitas vezes, com os demais trabalhadores do grupo. Essa evocação, convocação, inquietude pelo trabalho, estava intrínseca nos próprios trabalhadores e pôde ser vivenciada pelo pesquisador em vários momentos.

Certo dia, quando o operador Evandro estava em pé ao lado da máquina no posto de autocontrole, estático, com o controle da máquina na mão, ao ser questionado sobre o porquê de estar segurando o controle da máquina, ele prontamente e sorridente respondeu:

"É que se acontecer alguma coisa eu paro a máquina na hora, não preciso ir ao painel principal. Ninguém faz isto, só eu que faço. [...] Os outros nunca atentaram para isto não, mas se eu posso prevenir os problemas aqui, não vou vacilar".

O mesmo aconteceu com o auxiliar Leônidas, que, após ligar a bobinadeira, permaneceu o tempo todo de operação com o dedo posicionado em cima do botão de desligar a máquina. Ao ser questionado quanto ao porquê daquela sua atitude, ele respondeu com um discurso complementar ao do operador Evandro: 
"Se precisar parar a máquina rápido, eu já estou pronto. [...] Eu não confio nesta máquina. Ela pode dar um tranco rapidamente e eu preciso parar a máquina. Então, já estou preparado".

As falas demonstraram o estado de prontidão, de alerta dos trabalhadores para qualquer situação vinculada às suas atividades de trabalho e corroboraram vários elementos da gestão, presentes no embasamento teórico analisado e presente nas atividades de trabalho destes operadores.

As constatações demonstraram que as situações de trabalho exigiam do trabalhador um esforço de aprendizado e adaptação, o que culminava na reconstrução de sua experiência adquirida no decurso de sua vida laboral e social. Sendo assim, o trabalhador, ao se deparar com situações similares, fazia uso de sua cognição, de suas experiências passadas, usando o conhecimento adquirido para resolver ou evitar problemas presentes - dentre outros, o caso do processo de soldagem descrito e analisado pareceu bastante ilustrativo. Na verdade, é essa cognição, é esse conhecimento adquirido que possibilitavam ao trabalhador obter sucesso em suas atividades, pois "no final sempre tem aquele detalhe da experiência que você pega com o dia-a-dia e você usa isto e é isto que faz a diferença" (CLAYTON, operador chefe de processo).

Essas apreensões sobre o trabalho somente são possíveis numa pesquisa com base na concepção de valorização dos saberes práticos - o segundo polo - e cujos meios - método - permitam essa aproximação com a realidade do trabalho, buscando-se estar próximo dos trabalhadores para entender suas formas de engajamento com o trabalho, também denominadas co-engendramento e, cujas situações estão permeadas de valores e dramáticas em curso nas atividades por eles geridas cotidianamente - no efetivo ato de trabalhar e experimentar. As reuniões de validação nesta pesquisa buscaram aproximar o trabalhador das suas atividades de trabalho de modo a trazer o conhecimento do observável para a reflexão destes sujeitos enquanto fazedores de história.

\section{Considerações finais}

Na realização desta pesquisa, buscou-se imergir no ambiente de trabalho, intentando conhecer os trabalhadores no campo social e profissional, pois o trabalhador é um só - corpo si -, não deixa em casa parte de si quando vai trabalhar. É o mesmo homem que ingressa na empresa e retorna para o seu lar, levando consigo experiências e vivências tanto laborais quanto sociais, inquietações e aptidões, assim como interage, cria e se constrói no decurso de seu trabalho e de sua vida cotidiana.

Como meio de apreensão das formas de engendramento do trabalhador com o seu trabalho e porque não dizer com seus pares, buscou-se a compreensão do contexto no qual o mesmo está inserido, sob a perspectiva de que o meio é parte importante neste processo de construção do trabalho e de suas subjetivações, que se transformam em gestões do cotidiano. Percebeu-se desse modo, conforme abordado, que o ser humano, no ato industrioso se evoca por inteiro, interagindo com todos os aspectos do trabalho desde as gestões das nuances, dos detalhes, até as gestões das atividades, sempre existentes em qualquer processo de trabalho — recentrando as normas.

Os trabalhadores são convocados por inteiro e, devido a isso, buscam corresponder aos anseios da organização, que muitas vezes se confundem com os seus, fazendo usos de si por si e vivenciando usos de si por outros. Compreendeu-se assim, que o trabalhador está sempre presente e atento em todos os atos do seu trabalho realizando antecipações. Ele não é uma máquina sem sentimentos ou emoções, pelo contrário, ele age e reage de forma motivada em diferentes situações de trabalho. Ele sempre está ali integralmente, realizando gestões, ações, interações e articulações, pois o trabalhador, para exercer seu ato de trabalho, tem que tomar decisões, às vezes microdecisões, assumir responsabilidades que os gerentes organizacionais, com sua concepção formal do trabalho, muitas vezes não reconhecem.

Durante o período de acompanhamento pôde-se perceber que o trabalhador, ao fazer usos de si para enfrentar as demandas do seu trabalho, permite que suas capacidades sejam requeridas e aprimoradas constantemente, tramitando entre a situação atual e real do trabalho às possibilidades futuras - fazendo história. A compreensão da singularidade e complexidade do trabalho fez emergir um olhar plural sobre o trabalhador, que permite entendê-lo como ser humano: racional, com instintos, emoções, necessidades, escolhas e decisões. 
Decisões que são tomadas, muitas vezes, com base em experiências passadas com ação no presente e efeito no futuro, pois o trabalhador, ao realizar o seu trabalho, sempre o transforma, renormatizando-o a partir de suas superações, como forma de "enfrentamento" das suas imposições.

Essas percepções evidenciaram que não é possível definir ou antecipar as atividades humanas no trabalho, pois o trabalho é o encontro de uma diversidade de experiências singulares e em transformação. O trabalho coloca o indivíduo frente às escolhas do uso de si a fazer e o meio considerado contribui para reescrever as configurações futuras, pois as possibilidades de renormatizações são infindáveis. Assim, compreendeu-se que, no ato de trabalhar, sempre está implícita a parcialidade e a temporalidade dos conhecimentos elaborados e adquiridos, pois o trabalho é dinâmico, está em constante mutação.

A utilização dos conceitos da ergologia pode propiciar uma perspectiva de análise alternativa para o estudo do trabalho nas organizações, que busca elucidar as complexidades e singularidades das atividades de trabalho, intentando compreender o trabalho onde e como acontece. Nesse sentido, é buscada a interação com o trabalhador de forma que o mesmo seja compreendido como um dos polos éticos do conhecimento e elemento plural para se transformar o trabalho - responsável pelo ato de criar.

Logo, a concepção de trabalho como uso de si, uso de si por outros e uso de si por si, exprime, conforme os conceitos apresentados anteriormente, a condição humana de o homem querer ser sujeito de suas próprias normas. É essa condição humana que faz do trabalho um lugar de debates e enfrentamentos de normas, conhecimentos e valores nos atos de trabalho (SCHWARTZ, 2000a).

Como aspectos mais específicos, o pesquisador enfatiza que, após o período de pesquisa (cerca de um ano considerando trabalhos de campo, reuniões, entrevistas até o fim da análise dos dados construídos), percebeu que os conceitos da ergologia podem propiciar processos de transformação das situações de trabalho. Após os estudos aqui iniciados, o conceito de prescrição da empresa estudada pôde ser transformado. Após as intervenções, optou-se por construir instruções de trabalho que contemplem os objetivos e parâmetros do processo e não os modos operatórios, mudando o foco do "como fazer" para "o que fazer"; além dos elementos da ordem do imponderável que o processo todo proporcionou.

Devido à imensidão desse objeto de estudo, é sabido da singeleza dessa pesquisa, que serviu como forma de inquietação para que novos estudos possam ser realizados, pois não se consegue abordar em plenitude a atividade de trabalho, o trabalho real e toda a complexidade do que há de humano num só ato de trabalho. Assim, espera-se que novos trabalhos possam ser suscitados, no intuito de elucidar novos aspectos para as situações de trabalho vivenciadas, que remetam à importância da dimensão do 'gerir a gestão do trabalho' . 


\section{Referênclas}

ABRAHÃO, Júlia Issy; PINHO, Diana Lúcia Moura. As transformações do trabalho e desafios teórico-metodológicos da ergonomia. Estudos de Psicologia, Natal, v. 07, 2002.

BARROS, Maria Elizabeth B.; FONSECA, Tânia M. G. Psicologia e processos de trabalho: um outro olhar. PSICO - Revista da Faculdade de Psicologia da PUC-RS, Porto Alegre, v. 35, n. 2, p. 133-139, jul./dez. 2004.

BOUTET, Josiane. et al.. Le monde du travail - introduction. Paris: La Découvert, 1998.

CLOT, Yves. A Função Psicológica do Trabalho.Petrópolis: Editora Vozes, 2006.

DANIELLOU, François (org.). A Ergonomia em busca de seus princípios: debates epistemológicos. São Paulo: Edgard Blücher, 2004 .

DANIELLOU, François; LAVILLE, Antoine; TEIGER, Catherine. Ficção e realidade do trabalho operário. Paris: Lês Cahiers Français, n. 209, 1983.

DEJOURS, Christophe. A loucura do trabalho. 5. ed. São Paulo: Cortez - Oboré, 1991.

DEJOURS, Christophe; ABDOUCHELI, Elisabeth; JAYET, Cristian. Psicodinâmica do trabalho. São Paulo: Atlas, 1994.

FIGUEIREDO, Marcelo. et al (orgs.). Labirintos do trabalho: interrogações e olhares sobre o trabalho vivo. Rio de Janeiro: DP\&A, 2004 .

GODOY, Arilda Schmidt. Pesquisa qualitativa: tipos fundamentais. Revista de Administração de Empresas, São Paulo: FGV, v. 35, n. 2, p. 57-63, mar./abr. 1995 a.

Pesquisa qualitativa: tipos fundamentais. Revista de Administração de Empresas, São Paulo: FGV, v. 35, n. 3, p. 21-29 maio/jun. 1995b.

GUÉRIN, F. et al. Compreender o trabalho para transformá-lo: a prática da ergonomia. São Paulo: Edgar Blücher: Fundação Vanzolini, 2004.

KAWAKAMI, Tsuioshi et al. Participatory approaches to improving safety and health under trade union initiative. Industrial Health, Tokyo, n. 42, p. 196-206, 2004.

MACHADO, Leila Domingues; BIANCO, Mônica de Fatima; PETINELLI, Susane. Apontamentos sobre o cotidiano de alguns trabalhadores. CRITEOS, 2006.

SCHWARTZ, Yves. Trabalho e valor. Tempo Social - Revista de Sociologia da USP, São Paulo, v. 8, n. 2, p. 147-152, out. 1996.

Os ingredientes da competência: um exercício necessário para uma questão insolúvel. Educação \& Sociedade, Campinas, v. 19, n. 65, p. 101-140, dez. 1998.

Trabalho e uso de si. Revista Pró-Posições: Faculdade de Educação/Unicamp, Campinas, v. 1, n. 5 (32), p. 34-50, jul. $2000 a$.

A comunidade científica ampliada e o regime de produção de saberes. Trabalho \& Educação, Belo Horizonte, n. 7, p. 38-46, jul./dez. 200ob.

Trabalho e saber. In: CONFERÊNCIA DE ABERTURA DO SEMINÁRIO TRABALHO E SABER. Seminário Trabalho e Saber, Belo Horizonte, maio 2003.

. Trabalho e saúde: construindo outros modos de gestão. Tradução de Anna Luiza Telles Kirsch. ABRASCO, Florianópolis, Jul. 2005 .

YIN, R. K. Estudo de caso: planejamento e métodos. 3. ed. Porto Alegre: Bookman, 2005. 